\title{
AS TESSITURAS DA LIBERDADE NO PERNAMBUCO OITOCENTISTA (RECIFE: 1883 E 1884)
}

\author{
José Bento Rosa da Silva ${ }^{1}$
}

\begin{abstract}
Resumo
$\mathrm{O}$ artigo investiga dois processos cíveis envolvendo africanos e crioulos na cidade do Recife, nos anos de 1883 e 1884. No primeiro processo analisado, uma escravizada reivindica sua liberdade, a partir do argumento de que era africana livre, pois que desembarcara no Império do Brasil após a Lei de 7 de novembro de 1831. O processo revela que outros africanos desembarcaram com ela no mesmo navio negreiro na região do Cabo de Santo Agostinho. Esses malungos - companheiros de barco - foram as testemunhas no processo movido contra a senhora de Maria, corroborando a tese de que era uma africana livre. O segundo processo é emblemático, tratase de uma mãe brigando na justiça contra a reescravização de sua filha, que teria o direito à liberdade por haver sido abandonada por sua senhora, em virtude de estar doente. Amparada na Lei de 28 de setembro de 1871, ela busca o direito à liberdade da filha.
\end{abstract}

Palavras-Chave: liberdade; lei, africanos; processos.

\section{Résumé}

L"article examine deux affaires civiles impliquant des africains et des créoles dans la ville de Recife, dans les années 1883 et 1884 . Dans le premier processus analysé, une femme esclave réclame sa liberté de l"argument qu"elle était africaine libre, puisqu"elle avait atterri dans l'Empire du Brésil après la Loi du 7 novembre 1831. Le processus révèle que d"autres africains ont débarqué avec elle sur le même navire négrier dans la région de Cabo de Santo Agostinho. Ces malungos camarades de bord - étaient les témoins du procès intenté contre la dame de Marie, corroborant la thèse selon laquelle elle était une africaine libre. Le second cas est emblématique, c"est une mère qui se bat au tribunal contre le changement de marque de sa fille, qui aurait le droit à la liberté parce qu'elle a été abandonnée par sa maîtresse, parce qu"elle était malade. Soutenue par la Loi du 28 septembre 1871, elle cherche le droit de la fille à la liberté.

Mots-clés: liberte; loi; africains; procès.

1Possui graduação em História pela Fundação do Pólo Regional do Vale do Itajaí (1985), mestrado em História pela Pontifícia Universidade Católica de São Paulo (1994) e doutorado em História pela Universidade Federal de Pernambuco (2001). Atualmente é professor associado da Universidade Federal de Pernambuco. Tem experiência na área de História, com ênfase em História da África. Vinculado ao Centro De Estudos Africanos da Universidade do Porto(Portugal- 2002/2016) como investigador doutorado. Estágio pós-doutoral na Université Jean Jures - Mirail I [Toulouse- 2014-2015].Vice-coord. do Instituto de Estudos da Africa na Universidade Federal de Pernambuco[20162017].Vice-coord. do Núcleo de Estudos Afro-brasileiros da Universidade Federal de Pernambuco[NEAB].Membro do Núcleo de Estudos de Identidades e Relações Interétnicas da Universidade Federal de Santa Catarina [NUER-UFSC]. 
Que noite mais funda, calunga No porão de um navio negreiro Que viagem mais longa, candonga Ouvindo o batuque das ondas Compasso de um coração de pássaro No fundo do cativeiro

Roberto Mendes - Massemba

Liberdade - essa palavra que o sonho humano alimenta: que não há ninguém que explique, e ninguém que não entenda!

Cecília Meireles -Romanceiro da Inconfidência

\section{As Leis de 1831 e 1871 e as ações de liberdade: à guisa de introdução}

A Lei de 7 de novembro de 1831 ficou conhecida popularmente como "Lei Para Inglês Ver", pois, segundo essa interpretação, ela não teria saído do papel, qual seja, não havia sido cumprida. Mas do que se tratava esta lei e qual sua eficácia no contexto do conturbado período da regência no Brasil Imperial?

Segundo Moura (2004), a referida lei foi promulgada no período da regência exercida por Lima e Silva, Bráulio Muniz e Costa Carvalho, quando era ministro da Justiça o padre Diogo Feijó. Essa lei foi, na verdade, a tentativa de fazer cumprir o tratado assinado com a Inglaterra em 1826 e ratificado em 1827, segundo o qual o Brasil deveria proibir definitivamente o tráfico de escravizados da África. Nesse sentido, os africanos desembarcados no Império do Brasil, após esta lei, seriam considerados africanos livres e o tráfico se tornaria contrabando. Moura (2004) afirma categoricamente que a lei jamais foi cumprida, apesar de estabelecer as seguintes penas para os traficantes: pena corporal, multa de trezentos mil réis por cabeça de escravizados, responsabilidade pelos custos com a repatriação dos contrabandeados (MOURA, 2004).

A lei continha nove artigos, mas importam aqui o preâmbulo e o artigo primeiro:

A Regência em nome do Imperador o Senhor D. Pedro II faz saber á todos os Súditos do Império, que a Assembléia Geral decretou e ela sancionou a Lei seguinte:

Artigo $1^{\mathrm{o}}$. Todos os escravos, que entrarem no território ou portos do Brasil, vindos de fora, ficam livres. Excetuam-se: 
1. Os escravos matriculados no serviço de embarcações pertencentes ao país onde a escravidão é permitida, enquanto empregados no serviço das mesmas embarcações. 2. Os que fugirem do território ou embarcações estrangeiras, os quais serão entregues aos senhores que os reclamarem, e reexportados para fora do Brasil. Para os casos de exceção n. 1, na visita da entrada se lavrará termo do número de escravos, com as declarações necessárias para verificar a identidade dos mesmos, e se fiscalizará na visita da saída se a embarcação leva aqueles com que entrou. Os escravos, que forem achados, depois da saída da embarcação, serão apreendidos e retidos até serem reexportados. (BRASIL, 1831).

Os jornais denunciaram inúmeros casos de contrabando de africanos após esta lei ter sido sancionada. Muitos processos cíveis de ação de liberdade também tiveram como escopo a mencionada lei. Portanto, mesmo que a medida legal não tenha sustado o tráfico, ela serviu como base para as reivindicações de liberdade dos proponentes das ações, como foi o caso de Maria, uma das personagens de nossa investigação.

A Lei de 28 de setembro de 1871, conhecida como Lei do Ventre Livre, também abriu possibilidades para a liberdade, malgrado a precariedade dessa almejada condição de liberto. É o que veremos também neste artigo, quando duas libertas disputavam a posse de uma parda.

\section{Maria - africana - e seus malungos: em face da lei}

Corria o ano de 1884, no mês de outubro, mais precisamente no dia 6, na cidade do Recife, o escrivão Felicíssimo D’Azevedo Mello autuou a seguinte petição:

\section{Ilmo. Excelentíssimo Senhor Doutor Juiz de Direito do Cível.}

Maria, africana, de idade de 50 anos, poucos mais ou menos, achando-se em poder de Rita Maria da Conceição, residente nesta cidade, como cativa, querendo tratar de seus direitos, visto ser livre em face da lei, vem requerer a Vossa Excelência, se digne nomear um curador afim de defender os direitos da suplicante.

Nestes termos, pede deferimento [...]

Recife, 6 de outubro de 1884. (MJP; CR; processo cível; caixa 1161; ano 1884; folha 2).

Maria não sabia ler nem escrever, por isso, quem peticionou a seu pedido (a rogo) foi Francisco Augusto de Miranda. Pouco sabemos sobre esse senhor, mas, com certeza, ele tinha 
algum interesse na liberdade de Maria. Seria um abolicionista? É importante lembrar-se do impacto do movimento abolicionista da vizinha capitania do Ceará na capital da província de Pernambuco. Foi justamente no ano de 1884, mais precisamente a 25 de março, que se deu a abolição da escravidão naquela província. Os jornais do Recife registram manifestações de apoio pelas ruas do Recife. No Teatro Santa Isabel, foram apresentados recitais de música e poesia (SANTOS, 2015). Não por acaso, foi no mesmo outubro de 1884 que se fundou no Recife o clube abolicionista denominado: Clube do Cupim.

Adelino Antônio de Luna Freire Júnior foi nomeado para curador de Maria, já no dia seguinte. Como de praxe, seguindo os ritos jurídicos, fez o juramento devido. Em seguida, o curador solicitou ao juiz de direito da vara civil do Recife que Maria ficasse à disposição do Depositário Geral na forma da lei. No dia 9 de maio, foi cumprido o mandado de depósito:

Termo de depósito.

Recife, no escritório do depósito geral, o capitão Manoel Antônio ${ }^{2}$, onde fomos vindos, nós [folhas 06v] oficiais do juízo abaixo assinado, em virtude do mandado retro, depositamos a preta Maria [escrava] de que trata o mesmo mandado, em mãos e poder do dito depositário geral, quem da dita escrava ficou de posse na forma da lei, e para constar lavramos este termo em que assinamos com o depositário. (MJP; CR; processo cível; Caixa 1161; ano 1884; folhas 06-06v).

Foi marcada a primeira audiência para o dia 8 de novembro do mesmo ano de 1884 . A acusada não compareceu à audiência, deixando "a ver navios" as autoridades: o juiz de direito do cível, Joaquim da Costa Ribeiro; o juiz de órfãos, Adelino Antônio de Lima Freire Júnior; e o escrivão, Felicíssimo D’Azevedo de Melo.

Dona Rita Maria da Conceição, a proprietária de Maria, já dava a causa por perdida, segundo o oficial de justiça, Pedro de Alcântara:

Certifico que nesta cidade citei a suplicada dona Rita Maria da Conceição por todo conteúdo na petição retro, da que ficou entendida, e nesta ocasião a suplicada me declarou que nada se opunha sobre a liberdade da referida escrava, pois que já a considerava livre.

$2 \mathrm{O}$ capitão Manoel Antônio Gonçalves foi nomeado para o cargo de Depositário Geral da comarca de Recife em 6 de julho de 1881, conforme registro do Diario de Pernambuco: "Serviço Particular do Diario pelo telégrafo terrestre. Rio de Janeiro, 5 de julho, às 3 e 25 minutos da tarde, recebido às 4 horas e 35 minutos, para depositário geral da comarca do Recife, em Pernambuco, foi nomeado o capitão Manoel Antônio Gonçalves". (DIARIO DE PERNAMBUCO, 6 de julho de 1881). 
O referido é verdade, e dou fé.

Recife, 4 de novembro de 1884

Oficial de justiça - Pedro de Alcântara.

(MJP; CR; processo cível; caixa 1161; ano 1884; folha 08v).

O curador de Maria requereu que "em vista da sua declaração, seja passada a carta de liberdade a sua curatelada". A despeito da declaração de Maria Rita da Conceição e do requerimento de Adelino Antônio de Luna Freire Júnior em favor da suplicante, o processo não foi encerrado, ele estendeu-se até julho do ano seguinte.

Entre as testemunhas arroladas em defesa da liberdade de Maria, estavam três africanos que conseguiram alcançar suas liberdades em virtude da lei de 7 de novembro de 1831. Eram: Joaquim, Narciso e José de Mattos. Segundo seus depoimentos, vieram no mesmo barco em que Maria fora embarcada compulsoriamente; todos originários do Congo. Do rol das testemunhas nos chamou a atenção José de Mattos, pelo fato de ter um sobrenome - era raro escravizados com nomes compostos (nome e sobrenome), pois, no processo de tráfico, seus nomes africanos eram suprimidos e outros lhes eram atribuídos na hora do batismo. Eram identificados pelo local de origem, ou pela suposta etnia. No caso, os três eram congos. Não conseguimos saber muito mais sobre este José de Mattos, pois no processo não consta seu depoimento.

As testemunhas foram ouvidas no dia 13 de junho de 1885. Joaquim Congo, de 50 anos de idade, "pouco mais ou menos", solteiro, africano, morador na cidade do Recife, na localidade de Santana das Salinas. Sua profissão era de caiador, não sabia ler nem escrever. Ele disse que:

[...] conhece a preta africana, de nome Maria, e sabe que foi ela importada para este Império e Província, há quarenta e tantos anos, que sabe disto por ter sido ele também importado de parceria com a mesma Maria e por esse mesmo motivo já foi ele, testemunha, julgado livre por haver provado, [disse] que Maria foi batizada [folhas 013v] de parceria com ele, testemunha, na Vila do Cabo para onde foram todos conduzidos. (MJP; CR; processo cível; caixa 1161; ano 1884; folhas 013-013v.).

O depoimento de Joaquim é revelador: foram batizados na capela da Vila do Cabo de Santo Agostinho. Isso indica que, apesar do tráfico ilegal, havia no mínimo conivência da Igreja Católica, preocupada em batizar. Talvez até tenham denunciado, mas a preocupação primeira era com a alma dos cativos. Nesse sentido, estavam seguindo as orientações das instituições às quais pertenciam (VAINFAS, 1986). É certo que foi com o batizado que a africana se "metamorfoseou" em Maria. 
Sabe-se lá que nome ela tinha antes.

Na Vila de Santo Agostinho, havia um porto, até hoje conhecido como "Porto de Galinhas". A denominação era uma senha que indicava a chegada de escravizados clandestinamente: "chegou galinha de angola no porto". Os jornais denunciavam as suspeitas de desembarques clandestinos nessa localidade. Malgrado as denúncias, as autoridades, em sua maioria, faziam vistas grossas. Um dos casos mais escandalosos foi o desembarque de Sirinhaém que repercutiu por meses nos jornais locais (FERNANDES, 2010). Até os religiosos do Carmo foram acusados de escravizar africanos livres desembarcados ilegalmente nesse caso (DIARIO DE PERNAMBUCO, 27 out. 1855).

A segunda testemunha ouvida foi Narciso Congo, de 56 anos de idade, solteiro. Embora declarar-se congo, diante do escrivão, anota que era natural da costa africana; portanto, vê-se que as categorias congo e costa da África eram muito genéricas. Ele era morador da freguesia do Recife, tendo como profissão carregador de água. Não sabia ler nem escrever. Seu depoimento revelou mais acerca de Maria e do cotidiano dos africanos desembarcados após a lei de 7 de novembro de 1871, a situação dos denominados africanos livres:

Sendo inquirido, disse que esteve em casa de dona Rita da Conceição, que Maria é africana e veio para esta terra com ele, testemunha, e outros pretos, desembarcando à noite no Porto de Galinhas, seguindo depois para a Vila do Cabo onde foram todos batizados de uma só vez [folhas: 014]; que isto teve lugar há quarenta anos, mais ou menos, que Maria quando aqui desembarcou era menina, que ele testemunha dias depois de ter ido para o Cabo, pode fugir com um outro parceiro, que fora pegado aqui no Recife pela polícia e mandado para o Arsenal da Marinha, onde esteve até antes da guerra do Paraguai, e que por isto sabe que Maria veio para esta terra depois que o governo proibiu que os africanos aqui desembarcassem, tanto que muitos de seus parceiros foram pegados pela polícia na ocasião do desembarque. (MJP; CR; processo cível; caixa. 1161; ano 1884; folhas 013v-014).

Após o desembarque clandestino em Porto de Galinhas, o destino reservou aos malungos desencontros, mas também encontros, como foi o caso de Maria e Narciso, mesmo antes de estarem juntos na sala das audiências para provarem a liberdade de Maria. Narciso disse que havia visitado Maria na casa de Rita Maria da Conceição, sua senhora. Isso indica que talvez ele já estivesse em liberdade, visto que se libertara antes dela. E mais, lembra muito bem de Maria menina, embora oficialmente a diferença de um para com o outro fosse apenas de seis anos. Talvez tenha sido nessas visitações que combinaram que ele, Narciso, pudesse testemunhar em favor dela, que ainda residia sob o jugo da escravidão. Escravizados e libertos constituíam redes de solidariedade, neste caso, as 
redes foram tecidas já no porão do navio, ouvindo as ondas do mar, em meio às longas noites de travessia da calunga grande.

A Guerra do Paraguai foi um dos suportes da memória do depoente, e não foi por acaso; aquela "maldita guerra" sorveu o sangue de muitos africanos escravizados, bem como dos crioulos na mesma escravidão (CHIAVENATO, 1987). Dessa forma, a guerra acabou sendo um divisor de águas na memória de alguns escravizados, como parece ter sido o caso de Narciso, que havia fugido, mas que fora capturado e levado para o Arsenal da Marinha do Recife, onde ficara sob a "tutela" do Império do Brasil, na condição similar a de outros escravizados, mas na categoria de africano livre. Talvez tenha assistido alguns parceiros de Arsenal serem enviados para os campos de batalha da Guerra do Paraguai. Uma guerra que não era deles, mas que ficou na memória dos seus contemporâneos que contaram para os que vieram depois. Dessa forma, a guerra constituiu-se um lugar de memória.

O depoimento de Narciso fez com que perguntássemos pelas condições dos africanos livres no Arsenal da Marinha no Recife. O periódico Diario de Pernambuco nos possibilitou ver em que condições ficaram os africanos livres sob a "guarda" dessa instituição.

\subsection{O Arsenal da Marinha do Recife e os africanos livres}

O cotidiano dos africanos livres no Arsenal da Marinha foi também evidenciado por diversas notas do Diario: nascimentos, mortes naturais, acidentes, brigas, etc. "Consta-nos que no dia 26 deu-se um conflito entre alguns africanos livres que se acham recolhidos no arsenal da marinha do que resultou ficar um muito mordido, e outro com uma lesão na cabeça" (DIARIO DE PERNAMBUCO, 28 de janeiro de 1856). O jornal registrou outra desavença entre africanos livres no Arsenal da Marinha, embora não tenha mencionado os motivos, mas dessa desavença resultou a prisão de João III, por haver este ferido a também africana livre, Porcina, que estava a serviço da Casa dos Expostos (DIARIO DE PERNAMBUCO, 20 de maio de 1861).

Para além dos conflitos, havia os momentos de "indisciplina coletiva, que podemos acompanhar na notícia veiculada um dia após o natal do ano de 1860: "Pelas 6 1/2 [seis e meia] horas da tarde de 23 do corrente, diversos africanos livres do arsenal da marinha, andando a passeio, embriagaram-se, e neste estado, armados de paus e calabrotes, acometeram a várias pessoas, as 
quais foram distribuindo pancadas e calabrotadas [sic] a torto e direito" (DIARIO DE PERNAMBUCO, 26 de dezembro de 1856). Não foi registrada a prisão dos mesmos; tampouco sabe-se se essa "turnê" pelas ruas do Recife fazia parte do regimento interno do Arsenal, ou se foi uma saída sorrateira, posto que não era um dia de semana.

Era função do inspetor do Arsenal da Marinha comunicar as ocorrências ao curador dos africanos livres: visando cumprir o que lhe era de obrigação, o inspetor remeteu ao curador dos africanos livres um ofício, comunicando do desaparecimento no mar do corpo de Carlos II, "por haver [ele] caído da nova barca de escavação ao mar pelas 7 horas da manhã do dia 18 de junho [...] posto que seu cadáver não tenha aparecido" (DIARIO DE PERNAMBUCO, 27 de junho de 1861).

Um relatório do cirurgião da enfermaria do Arsenal da Marinha, Joaquim José Alves de Albuquerque, relativo ao ano de 1861, mostra que para aquele ano foram atendidos 101 africanos livres. As moléstias mais atendidas foram: "úlceras (18); contusões (10); bronquites e ferimentos (8); abscessos (6); vítimas de castigos e sífilis constitucional (5); reumatismo articular e erisipela (4), bexiga, diarreia e reumatismo muscular (3): anemia, angina, boubão sifilítico, hemeralopia, oftalmia e paralisia ophatalgia, cólica, (2): cophalalgia, cólica, condelomas, inflamação no pênis, epilepsia, fratura no braço, febre inflamatória, gangrena, otite, plurondina, parto, e tubérculos pulmonares (1)" (DIARIO DE PERNAMBUCO, 13 de janeiro de 1862).

O índice de mortalidade dos africanos livres era alto. Segundo uma nota de jornal do ano de 1856, morriam em média de três a quatro por dia, fato ironizado pelo autor da matéria, caracterizando-o como uma grande epidemia: "Segundo mostram as relações de mortalidade, desaparecem diariamente de três a quatro africanos livres por dia. Serão eles dos que estão prestando serviço aos particulares? Se são, daqui a pouco não existe um só. Grande epidemia!” (DIARIO DE PERNAMBUCO, 15 de março de 1856).

O Arsenal da Marinha também era lugar de nascimento de filhos de africanos livres. Seriam essas crianças consideradas livres? Qual seria o destino do filho da africana livre, Joanna, que veio à luz no Arsenal da Marinha, conforme nota oficial (DIARIO DE PERNAMBUCO, 28 de julho de 1854) do inspetor do Arsenal ao curador dos africanos livres? Ofício de igual teor, mas com mais detalhes sobre o nascimento da filha de Benvinda, africana livre ao serviço da Santa Casa de Misericórdia de Olinda:

[...] ao juiz dos feitos da Fazenda, inteirando-o de haver o provedor da Santa Casa de Misericórdia de Olinda, participado que a africana livre Benvinda, que se acha ao serviço do respectivo hospital, dera a luz no dia 25 de agosto 
último, uma criança do sexo feminino, de cor preta, a qual já foi batizada com o nome de Luiza. Também se comunicou ao curador dos africanos livres. (DIARIO DE PERNAMBUCO, 22 de setembro de 1854).

Importante notar que o ofício registra o rito do batismo da recém-nascida, o que nem sempre acontecia aos africanos livres, sobretudo quando os navios de contrabando eram apreendidos, razão da preocupação do bispo Dom João da Purificação Marques Perdigão. Visando sanar este desleixo, o referido bispo publicou no Diario de Pernambuco, na edição do dia 15 de setembro de 1856, uma circular, que também foi remetida à direção do hospital de caridade, uma semana após sua publicação no Diario. O teor era o seguinte:

Tendo nós na devida consideração a recepção do sacramento do batismo que deve ser administrado aos africanos livres apreendidos em diversos lugares e épocas, para que possam adquirir direito à própria salvação, e constandonos que alguns ditos africanos existem no estado de pagãos por tempo considerável [...] solicitamos da religiosidade de todos aqueles que presidem aos estabelecimentos públicos, onde residem os mencionados africanos, para que quanto antes façam instruir na doutrina cristã e batizar todos os que ainda não gozaram a ventura de receber o sacramento.

Narciso mencionou as fugas a partir da Vila do Cabo de Santo Agostinho, onde o desembarque clandestino era realizado à noite. Se a noite ajudava os traficantes, ajudava também os escravizados, que, mesmo sem conhecer a região, quando possível, fugiam de seus algozes, juntando-se com os que já haviam se constituído como "ladinos", como o caso de João Francisco, noticiado na coluna "escravos fugidos", do jornal Diario de Pernambuco, na edição de 13 de julho de 1881:

João Francisco, preto, 47 anos de idade, baixo, cabeça grande, rosto curto, boca grande, traz barba no queixo, anda curvado e tem um caroço nas costas do lado direito, contador de histórias, entende alguma coisa do ofício de carapina, desconfia-se que estes dois últimos escravos andem juntos para o lado da praia, Porto de Galinhas.

No depoimento de Narciso, bem como no de Joaquim, vê-se a presença de um representante da Igreja Católica, preocupada com a salvação das almas dos gentios africanos, afinal, ainda que em condições de ilegais, era preciso cuidar dessas almas, antes que elas se perdessem na vastidão do território, quem sabe aquilombando-se nos sertões, ou perdendo-se nos muquifos dos centros urbanos, tais como da cidade do Recife, que se constituíam uma dor de cabeça para os capitães do 
mato, chefes de quarteirões e demais autoridades.

\subsection{Africanos livres escravizados e reescravizados}

Maria e seus parceiros não foram os únicos africanos que entraram no Brasil após a lei de 7 de novembro de 1831; muitos outros passaram por esse processo. Nos jornais encontramos denúncias de envolvimento de algumas autoridades no tráfico ilegal, bem como de conivência. Até mesmo o Convento do Carmo foi citado. A ação de liberdade de Maria, africana, foi a ponta de iceberg, pois nos levou a outros casos no Recife oitocentista.

As denúncias de redução dos africanos livres à condição de escravizados perpassam várias edições. As décadas de trinta, cinquenta e sessenta foram as que mais registraram denúncias. Nem mesmo as instituições religiosas escapavam. Numa edição do ano de 1856, foi denunciado que no engenho dos religiosos do Carmo foram apreendidos dez africanos livres. O engenho estava arrendado a José Carlos de Mendonça. Geralmente estavam “disponíveis” para o comércio, quando um navio era aprisionado. Antes de serem recolhidos pelas autoridades, eram negociados na calada da noite. Há várias denúncias de sumiço de africanos livres apreendidos. O caso mais famoso foi o do aprisionamento de navio em Sirinhaém no ano de 1855, quando desapareceram sessenta dos aprisionados (DIARIO DE PERNAMBUCO, 27 de outubro de 1855).

Quanto ao caso dos africanos livres na propriedade dos religiosos do Carmo, o provincial da ordem religiosa veio a público esclarecer que o engenho Santo Elias estava arrendado ao senhor José Carlos de Mendonça e Vasconcelos. A redação do Diario de Pernambuco veio em defesa dos religiosos: "Evidentemente dever-se-á concluir deste anúncio, que os religiosos jamais poderão ser acusados de irresponsáveis por aqueles africanos encontrados em seu engenho, por estar arrendado ao senhor José Carlos” (DIARIO DE PERNAMBUCO, 14 de maio de 1856).

Um leitor do Diario, que se apresentou com o pseudônimo Protheo, perguntou por que não eram divulgadas, “aos quatro ventos" nos jornais, as apreensões de africanos. Corriam-se boatos de apreensões, mas, segundo Protheo, havia uma espécie de cortina de fumaça que impedia a visualização das apreensões. E pergunta mais: estariam sendo esses africanos livres repatriados para suas regiões de origem? Sem subterfúgios, denuncia que eles eram vendidos abertamente na cidade do Recife, no meio de outros produtos nacionais e/ou importados:

[...] Sabe-se muito bem que se tem feito algumas apreensões de africanos importados, mas já se viu alguma vez mencionar isso nas partes policiais? 
[...] Tem esses africanos sido transportados ao seu país, conforme o estipulado e nos tratado? [...] Às vezes se dão varejos em casas particulares (como há pouco mais de um mês na rua da praia e apreenderam-se cinco, foi isto participado? [...] $\mathrm{Na}$ rua direita eles apareciam na varanda entre macacos, passarinhos, esteiras e canudos de cachimbos. Qual foi o resultado? (DIARIO DE PERNAMBUCO, 16 de novembro de 1837).

Embora Protheo tenha feita a denúncia acerca do "silenciamento" das apreensões da importação ilegal dos africanos, ou melhor, disse que, quando se faziam, era a varejo, quando se sabia que a importação era em atacado, nas páginas do Diario, encontramos extratos de depoimentos feitos no Tribunal do Júri que revelaram alguns envolvidos. Esses extratos geralmente eram publicados a pedido de algum envolvido que, se dizendo inocente, buscava evidenciar a população que seu envolvimento não passava de calúnias a ele imputadas. E mais, muitas vezes os acusados eram absolvidos, outras vezes sequer eram denunciados, afinal sabiam que não ia dar em nada, conforme uma denúncia na edição de número 70 do Diario de Pernambuco, publicada numa quarta-feira, 27 de março de 1833, apenas dois anos após a lei de 7 de novembro que colocava o tráfico de africanos na ilegalidade:

Ao norte de Goiana desembarcaram aproximadamente trezentos e tantos africanos do contrabandista Gabriel Cambado, genro de João Cego, porém ninguém se quer propor a denunciar ao governo, para que não aconteça o mesmo que tem acontecido com os de Silva \& Cia., que se não sabe o que pretender o senhor ouvidor com um sumário tão delongado, salvo se é para dar tempo a que se reúnam estes a aqueles. Nota bem: os africanos apreendidos ao dito Silva já estão outra vez em seu poder, e não se sabe porque atenção.

Há também uma denúncia de furto de africanos livres vindos de Olinda, no ano de 1833. Segundo a nota, foram apreendidos trinta africanos novos pelo ouvidor Ângelo do Nascimento Crespo, mas que todos foram furtados, em uma noite, na casa onde estavam depositados (DIARIO DE PERNAMBUCO, 26 de junho de 1833). Em outros casos, havia autoridades envolvidas no tráfico ilegal, era "voz pública", como se dizia na época, e quando todos já sabiam, os jornais noticiavam com uma certa "normalidade". No caso mencionado, já haviam se passado vinte anos da lei de 1831: "É público que os grandes desembarques de africanos, que se tem efetuado na costa de Pernambuco e Alagoas são protegidos pelo doutor Jacintho de Mendonça, delegado do termo de Porto Calvo [...]” (DIARIO DE PERNAMBUCO, 12 de junho de 1851).

Havia no Diario de Pernambuco, na década de trinta, uma seção denominada 
“Correspondências", onde os leitores, geralmente com pseudônimos, dirigiam-se aos senhores redatores e faziam suas críticas, denúncias, reclamos, etc. Um certo Anjo Gabriel dirigiu-se aos redatores para fazer denúncia do tráfico e uso dos africanos livres como escravos. De uma forma irônica, ressaltando, inclusive, o uso de nova terminologia para os africanos livres: colonos africanos. Foi mais longe, dizendo que, com a proibição do tráfico, o preço dos africanos subiu e que até os africanos doentes eram comercializados por um preço absurdo.

No processo de ação de liberdade de Maria, não foi possível saber o "preço" de mercado dos envolvidos, até porque, no caso de Maria, sua pretensa proprietária disse reconhecer a sua condição de livre. Também não sabemos se Rita Maria da Conceição foi a única dona de Maria. Mas uma coisa é certa, desde a infância que ela vivia na condição de escravizada, mesmo legitimamente sendo uma africana livre. Agora tratava-se de provar legalmente sua condição de livre.

\section{Em defesa da filha}

No dia 4 de setembro de 1883, na cidade do Recife, Isabel da Costa Maria dos Prazeres, africana liberta, de idade desconhecida, fez uma petição ao excelentíssimo juiz do cível em favor de sua filha, de cor parda, Francisca Maria dos Prazeres, com 20 anos, mais ou menos. Na ocasião, ela solicitava um curador para sua filha, que estava em vias de ser reescravizada pela crioula liberta, Luíza Maria da Costa.

No passado, Isabel vendera sua filha para Luíza. Tendo a filha adoecido por duas vezes, foi despejada por sua senhora, que não queria gastar com a enfermidade da escravizada. Nesse sentido, a alforria era também uma forma de os senhores se livrarem dos escravos indesejados, seja em virtude de crimes cometidos, ou como neste caso, por não querer (ou não poder) arcar com a enfermidade da escravizada. Essa prática constituía-se como crime previsto no artigo $6^{\circ}$, parágrafo $4^{\circ}$, da Lei de 28 de setembro de 1871, conhecida como Lei do Ventre Livre:

Art. $6^{\circ}$ Serão declarados libertos:

$[\ldots]$

$\S 4^{\circ}$ Os escravos abandonados por seus senhores. Se estes os abandonarem por invalidos, serão obrigados a alimental-os, salvo o caso de penuria, sendo os alimentos taxados pelo Juiz de Orphãos.

A leitura dessa petição inicialmente pode causar estranhamento aos "desavisados" que não compreendem a dinâmica e as contradições da sociedade escravista moderna, levando-os a se 
perguntarem: "como pode uma mãe vender sua filha como escrava?" Nesse caso, faz-se necessário questionarmos: em que condições Isabel vendera sua filha? Ela, tão liberta quanto Luíza, não teria condições de sustentar-se juntamente com a filha? Estaria Luiza em melhor condição do que mãe e filha? E mais: por que vender a filha justamente para uma egressa do cativeiro (liberta) e não para uma pessoa livre? Afinal, as condições dos libertos não eram tão seguras como se pode imaginar. A vida dos libertos consistia numa precariedade constante, a todo o momento deveriam provar sua condição de libertos (OLIVEIRA, 1988). Aliás, essa realidade foi retratada "na sétima arte" recentemente ${ }^{3}$. Estamos nos referindo ao filme de Steve McQueen, 12 Anos De Escravidão, produzido no ano de 2014. Na verdade, foi uma versão de uma história verídica, ocorrida na América do Norte no século XIX.

Nem precisamos recorrer à literatura ou à cinematografia da América do Norte para constatarmos essa realidade; no Brasil, sobretudo no período do comércio interno de escravizados, não foram poucos libertos do Nordeste que foram vendidos como escravos para o Sudeste e Sul, conforme constatou Luana Teixeira, em sua tese de doutoramento sobre o comércio de escravizados a partir de Alagoas (TEIXEIRA, 2016).

Outra possibilidade de interpretar a atitude da mãe ao vender a filha pode ser a busca por segurança para a mesma, uma prática existente no continente africano, antes da chegada dos estrangeiros naquelas terras, como evidenciam estudos historiográficos (DEL PRIORE, 2004; MELLASSOUX, 1995). É verdade que era outro o contexto, mas não nos esqueçamos de que Isabel viera daquele continente, podendo ter trazido essa prática para a conjuntura adversa. E mais: quando sentiu que a filha não estava sendo protegida pela sua senhora diante da doença, tratou logo de defendê-la.

Isabel, ao que nos parece, não queria que sua filha fosse mais uma nas estatísticas dos reescravizados, por isso solicitou ao juiz cível um curador para defendê-la. Essa atitude manifestada na petição não estaria motivada por algum abolicionista de plantão? Em que medida ela sabia dos seus direitos? Teria ela consciência de todos os artigos, parágrafos e incisos da lei de 28 de setembro de 1871, a denominada Lei do Ventre Livre?

Deve-se apenas atribuir aos escravizados a incapacidade de agirem por si mesmos? Ou seja, por estarem tão "coisificados" pela escravidão, não conseguiriam enxergar ou conhecer seus

3A numeração das artes refere-se ao hábito de estabelecer números para designar determinadas manifestações artísticas. O termo "sétima arte", usado para designar o cinema, foi estabelecido por Ricciotto Canudo no "Manifesto das Sete Artes", em 1912, publicado apenas em 1923. A numeração das demais artes: $1^{\mathrm{a}}$ Arte - Música (som); $2^{\mathrm{a}}$ Arte - Dança (movimento); $3^{\mathrm{a}}$ Arte - Pintura (cor); $4^{\mathrm{a}}$ Arte - Escultura (volume); $5^{\mathrm{a}}$ Arte - Teatro (representação); $6^{\mathrm{a}}$ Arte - Literatura (palavra). Disponível em: <https://pt.wikipedia.org/wiki/Numera\%C3\%A7\%C3\%A3o_das_artes>. Acesso /em: 26 jul. 2016. 
direitos, como se estivessem em um outro mundo: sem ouvir, sem pensar, sem apreender o que lhes ocorria ao redor? Em suma, como se fossem coisas? (REIS, SILVA, 1999; SLENES, 1999). Na verdade, pensar assim é reproduzir uma perspectiva historiográfica na qual os escravizados eram vistos como “coisas" (GORENDER, 1990), incapazes juridicamente, - como preconizava a legislação do sistema escravista -, embora fossem sujeitos.

Com o abandono de Francisca por parte de Luiza, a doente fora recolhida no Hospital Dom Pedro II, pela caridade pública, conforme dizem as testemunhas. O curador Francelino Bernardo Quintino, buscando dirimir dúvidas, solicitou ao diretor do Hospital Pedro II documento acerca do período de internação de Francisca, bem como a condição social da mesma:

Isabel da Costa Maria dos Prazeres, africana liberta, a bem do seu direito, precisa que vossa excelência digne mandar dar-lhe por certidão, se a paciente filha da suplicante, de vinte anos de idade, de nome Francisca Maria dos Prazeres, deu entrada no Hospital Pedro II em janeiro de 1882, como escrava, liberta ou livre, em termo que merece fé, para que a suplicante possa usar a mesma como lhe convier, em favor da mesma sua filha.

A rogo da suplicante.

Bacharel Francelino Bernardo Quintino (MJP; CR; processo cível; caixa 1176; ano 1883; folhas $03 v$ ).

O Hospital Pedro II, na época, era uma referência na capital da província pernambucana e fora inaugurado no ano de 1861. Antes de sua inauguração, foi promovido um baile em homenagem ao Imperador Pedro II, pela ocasião de sua passagem pelo Recife. A princípio atendia apenas os portadores de deficiências mentais. O hospital ficou por muitos anos sob a administração das irmãs de caridade da Santa Casa de Misericórdia, instituição que, não apenas no Recife, mas em muitas cidades brasileiras, se preocupou com a assistência médica para os menos favorecidos (BARBOSA, 2008). Talvez tenha sido nesse período que Francisca fora atendida pela caridade pública, conforme disseram as testemunhas. E mais: no documento em resposta à petição do curador de Isabel, o escrivão o identifica como Hospital de Misericórdia.

A resposta à petição foi redigida no mesmo dia 25 de agosto do corrente ano, pelo escrivão Pedro Souza, com o seguinte teor:

Certifico em vista do respeitável despacho supra, que em 26 de janeiro de 1882 entrou para o Hospital Pedro II, Francisca Maria dos Prazeres, natural 
desta província, parda, com 19 anos de idade, donde saiu curada [rasura] não constando nada sobre, se livre, escrava ou liberta.

Secretaria da Santa Casa de Misericórdia.

Recife, 25 de agosto de 1883.

O escrivão - Pedro Souza (MJP; CR; processo cível; caixa 1176; ano 1883; folhas $03 \mathrm{v}-04)$.

Chamamos a atenção dos acadêmicos para as revelações que as peças processuais acima nos apresentaram. Primeiramente não é possível, através delas, saber quanto tempo Francisca Maria dos Prazeres ficara internada no Pedro II, mas se depreende que na época ela tinha 19 anos de idade, no ano anterior ao início do processo. Era parda, provavelmente filha de um pai não africano; talvez um crioulo liberto ou livre, ou de um branco livre. Se bem que a categoria pardo(a) era carregada de ambiguidades, conforme as pesquisas de Jocélio Teles dos Santos (2005). Aliás, uma categoria polêmica até os dias atuais, que ganhou mais repercussão diante das políticas afirmativas do governo federal, no contexto étnico-racial.

A condição social de Francisca também não foi registrada no ato da internação, talvez por desleixo, pois, numa sociedade de estamentos, as classificações (tanto raciais, quanto sociais) eram preocupações das instituições, tais como as Casas de Misericórdia. Uma coisa é certa, ela era uma adulta e, segundo as testemunhas, era escrava da liberta Luiza Maria da Costa.

Em posse do documento expedido pelo escrivão do Hospital Pedro II, o bacharel Francelino Bernardo Quintino, requereu ao juiz a guarda de Francisca na condição de sua curatelada, mas o juiz argumentou que:

Para a manutenção requerida às folhas 05 , é mister provar a posse da liberdade, e se o caso é de abandono da escrava, e como se diz na mesma petição, é mister provar também o fato alegado, para confirmar a liberdade à suplicante.

Em qualquer das hipóteses que justifiquem o suplicante o descrito que tem como citação da suplicada.

Recife, 2 de setembro de 1883.

Ribas (MJP; CR; processo cível; caixa 1176; ano 1883; folha 07).

As respostas à resolução do excelentíssimo juiz cabiam ao curador de Francisca juntamente com o auxílio da progenitora da mesma, que não a queria sob o "julgo" de Luíza, por esta comportar-se como uma má senhora, ao ponto de, na hora da doença, abandonar a sua escravizada 
Francisca. Essa realidade era, como se dizia, "voz pública" nas ruas do Recife oitocentista, sobretudo no meio dos abolicionistas, em tempos do aguerrido Tobias Barreto ${ }^{4}$. Então era preciso alocar as testemunhas em prol da justa causa, qual seja; a manutenção da liberdade de Francisca Maria dos Prazeres.

Francelino Bernardo Quintino, no exercício da defesa de sua cliente, tratou de "municiar-se" de todas as provas contra aquela que se dizia senhora de Francisca, mas que, no entanto, deixara-a "na rua da amargura", quando da sua enfermidade. E mais, não só levantou a prova do abandono, como solicitou que o juiz anexasse o mesmo documento no processo em curso, no dia 24 de setembro do corrente ano:

O bacharel Francelino Bernardo Quintino, tendo sido honrado por Vossa Excelência com a nomeação de curador da guarda de Francisca, há mais de um ano abandonada por sua senhora, Luiza Maria da Costa, e vivendo na companhia de sua mãe Isabel da Costa Maria dos Prazeres como que são livres, sem contestação de pessoa alguma, tanto que nessa qualidade, tratoua no Hospital Pedro II em janeiro de 1882, como se vê de uma certidão que existe no cartório do excelentíssimo Major Cunha, aconteceu agora sua intitulada senhora querer escraviza-la, e como a curatelada da suplicante que livremente defendeu-se dessa pretensa escravidão, requer respeitosamente a Vossa Excelência digne mandar passar mandado de manutenção em favor da mesma, sendo intimada a sua dita senhora.

Pede a Vossa Excelência deferimento.

Recife, 19 de setembro de 1883 (MJP; CR; processo cível; caixa 1176; ano 1883; folhas [ilegível]).

O documento, que se "metamorfoseara" numa peça processual em defesa de Francisca, traz mais elementos para a análise: segundo o mesmo, fazia já um ano que Francisca havia sido curada e vivia sob o teto de sua mãe, como se livre fosse, sem nenhuma contestação de quem quer que fosse. Talvez a sua pretensa dona, Luiza, não soubesse da recuperação da sua "ex-escrava", mas, ao tomar conhecimento, logo reivindicara a posse da mesma. Dessa forma, só restava o testemunho público para provar efetivamente o abandono de Francisca por aquela que, agora, se dizia sua proprietária.

Não sabemos da enfermidade de Francisca, mas os hospitais na época tratavam "de um tudo", aliás, mais do que tratar, era um lugar onde os desvalidos encontravam acolhida, alguns ficavam à espera da morte, sob a caridade e orações das irmãs religiosas (sobre o nascimento dos hospitais, ver FOUCAULT, 1979). No caso específico do Pedro II, nos primeiros tempos, acolheu

4Sobre o envolvimento de Tobias Barreto com os processos cíveis de liberdade, ver: MJP; CR; processo cível; caixa 1161 , ano 1882 . 
em sua maioria os doentes mentais.

Era necessário ainda saber quem pagou as despesas hospitalares. Novamente o curador recorreu à direção do Pedro II para certificar-se legalmente sobre quem custeara o tratamento de Francisca, se bem que o que se dizia é que havia sido a caridade pública. Mas o que nos chama a atenção no documento lavrado pela direção do hospital é a condição da paciente, pois "presumia-se que ela fosse liberta":

O bacharel Francelino Bernardo Quintino, nomeado pelo excelentíssimo Dr. Juiz de direito do civil, curador da parda Francisca Maria dos Prazeres, que deu entrada no Hospital Pedro II em janeiro de 1882, litigando em juízo a liberdade da mesma, precisa a bem dos direitos da curatelada, que vossa excelência digne mandar certificar-lhe se quando a curatelada suplicante teve naquele Hospital, foi tratada as expensas da Santa Casa, ou de quem e qual a pessoa que a mandou tratar?

Em termo que faço fé.

Recife, 20 de setembro de 1883

Francelino Bernardo Quintino (MJP; CR; processo cível; caixa 1176; ano 1883; folha 06).

Passados dois dias, o já conhecido, Pedro Souza, secretário do Pedro II, respondeu a solicitação feita pelo bacharel, da forma seguinte:

[...] Certifico, em virtude do respeitável despacho supra que, Francisca Maria dos Prazeres foi tratada no Hospital Pedro II por caridade, por presumir que era livre.

Santa Casa do Pedro II.

Recife, 22 de setembro de 1883.

Pedro de Souza (MJP; CR; processo cível; caixa 1176; ano 1883; folha 06; grifo nosso).

O processo continha muitas rasuras, mas conseguimos obter alguns dados sobre as testemunhas: a primeira foi Tertuliano Rego Pinheiro, solteiro, com trinta e quatro anos de idade, natural da província, profissão artista; a segunda, João Batista Pessoa, 50 anos de idade, natural da província; a terceira, Máximo Francisco de Assis, branco, casado... Os demais dados são os comuns na identificação das testemunhas, conforme estabelecido no Código do Processo Criminal do Império. 
A julgar pelo desfecho do processo, as testemunhas corroboraram as denúncias feitas contra Luísa Maria da Costa, pelo curador, Francelino Bernardo Quintino, que, através da documentação referida acima, provou que Luísa, que reivindicava a posse da parda Francisca Maria dos Prazeres, filha da africana liberta, Isabel da Costa Maria dos Prazeres, a abandonara quando se encontrava doente. Também é patente que Isabel foi quem tomou a iniciativa de abrir o processo em defesa da filha; afinal, não era por acaso que o nome da escrava abandonada era exatamente o sobrenome da mãe (Maria dos Prazeres). Quanto ao pai nada sabemos, talvez ele fosse branco, a julgar pela cor atribuída à Maria dos Prazeres (parda), se bem que a categoria cor, no decorrer da Colônia e Império do Brasil, era muito "fugidia", como já dissemos anteriormente.

A sentença final, proferida pelo juiz, Joaquim Costa Ribeiro, no dia $1^{\circ}$ de fevereiro de 1884 , nos revela, dentre outras coisas, que Maria dos Prazeres após a sua cura, a partir da "generosidade pública", ficou vivendo "como se livre fosse" sem a mínima interferência daquela que se dizia sua proprietária. Portanto, houve efetivamente o abandono por parte de Luísa Maria da Costa. E mais, o fato de morarem ambas na mesma cidade caracterizou um agravante ao descaso por parte da proprietária. Amparado nas leis vigentes, o juiz deu o veredicto final: Francisca Maria dos Prazeres estava liberta. Mas em que consistia a vida de uma liberta no Brasil oitocentista? Na falta de uma documentação que pudesse nos apontar o cotidiano da agora (legalmente) liberta, Maria dos Prazeres, nos resta conjecturar a partir de outras experiências. Mas, antes disso, vejamos o despacho do meritíssimo juiz, após os cinco longos meses que durou a ação de liberdade:

[...] Vistos estes autos de ação de liberdade, em que é autora a parda Francisca, filha da africana liberta de nome Isabel e representada por seu curador, neste processo contra a ré Luiza Maria da Costa, que tendo esta possuída a autora como sua escrava, e quando adoecido, a ré em lugar de incumbir do tratamento e curativo como lhe cumpria, colocou-a para fora de sua casa, e expos à caridade pública, dizendo a ela que fosse viver como pudesse; que nestas condições foi a autora ter no hospital Pedro II, onde por caridade esteve recolhida como livre, e saindo curada, continuou a viver como livre, não constando eu a ré empregasse as diligências precisas para chama-la a seu poder, apesar de ser a residência de ambas nesta cidade, e de haver corrido mais de um ano que se deu o abandono, porque a 26 de janeiro de 1882, entrou a autora para o hospital, como se vê das folhas 03 e 06.

Julgo, portanto, a ação procedente para declarar, como declara, livre a autora, porque sendo escrava foi abandonada por sua senhora nas condições do artigo 76 do Regulamento 5135 de 13 de setembro de $1872^{5}$, e tem a seu

5“Considera-se abandonado o escravo cujo senhor, residindo no lugar, e sendo conhecido, não o mantém em sujeição, e 
favor o disposto no Artigo 6, parágrafo 4 da Lei de 28 de setembro de $1871^{6}$, e de conformidade com o Artigo 75, parágrafo 4 do citado Regulamento ${ }^{7}$, mando que passa-se a carta de liberdade.

Recife, 1 de fevereiro de 1884.

Joaquim Costa Ribeiro (MJP/CR; processo cível; caixa 1176; ano 1883; folhas $15-15 \mathrm{v})$.

Ao longo do processo, a ré Luísa Maria da Costa foi intimada a prestar depoimento, não comparecendo em nenhuma das audiências. Isso demonstra, em nossa opinião, que ela já havia dado o caso como perdido; talvez não esperasse que Isabel, a mãe de Francisca Maria dos Prazeres tomasse a iniciativa de defender a filha, que já constava com a idade de 20 anos. O sentimento de maternidade, somado ao de justiça, não deixou que a africana liberta deixasse sua filha sob o julgo de quem a desprezara na hora que ela mais necessitava. Sua filha era sim uma escravizada, tinha seus deveres frente à sua senhora, mas também tinha direitos. Ao que nos parece, tanto a mãe quanto a filha estavam cientes de seus direitos e deveres; caso não estivessem, não entrariam com o processo contra Luísa Maria da Costa.

\subsection{As possíveis trajetórias da liberta}

O processo de ação de liberdade movido contra a parda, liberta, Isabel Maria da Costa em favor da também parda, Francisca Maria dos Prazeres, filha da africana liberta, Isabel da Costa Maria dos Prazeres, não nos oferece pistas sobre o cotidiano da ex-escrava após receber a carta de liberdade, no entanto, há estudos que indicam as condições dos libertos de uma forma geral (nossas principais referências serão Maria Inês Cortês de Oliveira, Mary Karasch e Kátia Mattoso). Vamos aqui, inserir Maria dos Prazeres dentro deste contexto.

Ainda que estivesse liberta, Prazeres, como os demais libertos, carregava o estigma de ter vivido na condição de escravizada, portanto, a todo instante, tinha que provar sua liberdade, sobretudo no espaço urbano, onde circulavam as forças de repressão e de vigilância (chefe de quarteirão, delegados, subdelegados, etc.). Estava ausente a figura do feitor, mas nem por isso os escravizados - e mesmo os libertos - estavam longe da vigilância. Sem contar os que, desejando um escravizado, pudessem lançar mão de algum artifício para reescravizar libertos que perambulavam

não manifesta querer mantê-lo sob sua autoridade. [...]" (BRASIL, Decreto 5135 de 13 de novembro de 1872).

6 “ $§ 4 .^{\circ}$ Os escravos abandonados por seus senhores. Se êstes os abandonarem por inválidos, serão obrigados a alimentálos, salvo o caso de penúria, sendo os alimentos taxados pelo juiz de órfãos".

7 “ $\S 4^{\circ}$ Os escravos abandonados por seus senhores receberão igualmente do juízo, que julgar o abandono, as suas cartas". 
pelas vilas, vendendo-os para outras províncias. O clima de suspeição era uma constante, conforme relata Maria Inês Cortês de Oliveira (1988, p. 11): “encarregava-se a sociedade escravista de modo a perpetuar no ex-escravo as marcas de sua antiga condição servil. Mas os estigmas do cativeiro iam muito além do aspecto jurídico, determinando mesmo as próprias condições de vida do liberto". A autora elenca algumas proibições aos libertos, tais como: interdição à locomoção noturna, ao porte de armas, vedadas as dignidades eclesiásticas... E mais, as limitações eram hierarquizadas, sendo os mais prejudicados os africanos libertos, se comparados com os crioulos libertos. Soma-se a isso a questão de gênero, ou seja, as mulheres eram ainda mais vitimizadas. A mesma autora mostra que na sociedade escravista, sobretudo no meio urbano, as possibilidades de liberdade recaíam mais sobre as mulheres do que aos homens (sobre essa questão, ver também: KARASCH, 2000 e MATTOSO, 1982).

As possibilidades de trabalho não eram fáceis para os libertos, numa sociedade onde os escravizados, seus descendentes e os libertos carregavam as marcas dos "filhos de Cam", qual seja, o fardo da cor. Libertar-se, lembra-nos Oliveira (1988, p. 21), "não significava apenas adquirir novo estatuto legal, mais do que isto, significava sobreviver às próprias custas". No caso de Prazeres, não sabemos se de fato havia se reestabelecido totalmente da doença que a vitimara. Aliás, tampouco sabemos qual a doença que a vitimara, no entanto, sabemos que uma das causas mais comuns de morte dos escravizados, segundo Mary Karasch (2000), eram as doenças parasitárias e infecciosas, como a tuberculose. Outra mazela que acompanhava os libertos era o alcoolismo.

Quanto à ocupação ou ocupações exercidas por Maria dos Prazeres, é possível que tenha se dedicado a trabalhos domésticos e atividades correlatas à escravidão no meio urbano. É possível que ela tenha continuado vivendo com a mãe que a libertara das garras de Luísa da Costa; esta era uma das vantagens dos libertos, não corriam mais o risco de terem a família "destroçada" através da venda de seus membros (KARASCH, 2000).

O fato de tanto Luísa quanto Isabel terem o mesmo sobrenome não significa que eram parentes. Isabel, talvez por ter sido trazida da Costa da Mina, e Luísa pode ter acrescentado este sobrenome por ter sido escrava de algum senhor com o nome de família (sobrenome) da Costa. Não era incomum os libertos "assumirem" o sobrenome dos antigos senhores, como tivemos oportunidade de constatar em pesquisas anteriores. Isso poderia significar uma proteção, o sobrenome como um "capital simbólico" (SILVA, 2008).

Não bastava ser liberto, era preciso aparentar-se liberto, portanto, comprar um par de sapatos era um dos pré-requisitos; e até mesmo possuir escravos. A própria Francisca Prazeres foi comprada 
por uma liberta. "A vida de cativeiro ensinara ao liberto que ser livre era ser senhor e ser senhor era possuir escravos" (OLIVEIRA, 1988, p. 35). Alguns libertos conseguiram adquirir alguns bens: Luísa comprara Prazeres (embora não tenha tido capacidade para mantê-la, razão pela qual perdera no processo). Não temos informações sobre os bens da africana liberta, Isabel, mãe de Prazeres, mas sabemos que outro africano liberto, Joaquim da Silva Cunha, construiu um patrimônio avaliado em quatrocentos mil réis, a saber: "Uma pequena casa térrea, número dez, sita na Rua da Esperança, freguesia da Boa Vista, com portas, janelas, duas salas, um quarto, cozinha externa, quintal grande, murado no fundo, em aberto dos lados, tendo o solo foreiro e oitões singelos, reforçados por pilares à vista" (MJP; CR; processo cível; inventário de um africano; caixa 1223; ano 1867; folhas 13).

Maria dos Prazeres, com 20 ou 21 anos de idade, apesar de ter passado por uma internação no Hospital Pedro II, talvez estivesse nos pré-requisitos anunciados pelos jornais, conforme registrou Karasch (2000, p. 472): “o mais comum eram anúncios de libertas, tais como 'pretende-se alugar uma mulher mulata, liberta e dotada de todas as boas qualidades, que a tornam capaz de cuidar do arranjo de qualquer casa"'. O certo é que Prazeres estava inserida no contexto do mundo dos libertos, com seus outros. Consultando os processos cíveis do período compreendido entre as décadas de 70 e 80 do século XIX, sobretudo aos anos próximos à abolição formal da escravidão, encontramos várias ações de liberdade, inclusive de africanos, reivindicando sua liberdade em virtude da Lei de 7 de novembro de 1831, denominada por uma certa historiografia brasileira como: "lei pra inglês ver" . Essa expressão sugere que foi uma lei inócua, mas, na verdade, houve sim, africanos que, tomando conhecimento dos seus direitos, reivindicaram suas liberdades a partir dela ${ }^{9}$

Embora os processos de liberdade que consultamos estivessem na Comarca do Recife, muitos deles referiam-se a vilas ou freguesias do entorno da capital da província. Identificamos muitos oriundos de Escada e Itambé. Não quantificamos, mas evidências apontam para um grande movimento oriundo dessas duas localidades. É possível que o destino dos libertos fosse engrossar o mundo dos libertos da cidade do Recife; portanto, Maria dos Prazeres era uma entre muitas que perambulavam pelas ruas do Recife, correndo todos os riscos possíveis e imagináveis de ser reescravizada. Não podemos falar muito mais sobre ela, uma vez que as pistas são escassas... Parece-nos que a vimos sumindo, virando a curva em uma da ruas ou becos da cidade. Ruas e becos

8“LEI PARA INGLÊS VER. Termo como ficou conhecida a lei de 7 de novembro de 1831, promulgada na Regência, então exercida por Lima e Silva, Bráulio Muniz e Costa Carvalho, sendo ministro da justiça o padre Diogo Feijó. A lei era precisa: declarava livres todos os escravos que, vindos de fora entrassem em território brasileiro". (MOURA, 2004, p. 240).

9Maria, africana, foi uma das que, em 1884 entrou com uma ação de liberdade, justificando que fora importada como escravizada para o império do Brasil, após a lei de 1831. Teve como testemunhas outros libertos que foram "companheiros de barco" e que já haviam conquistado suas liberdades em virtude da referida lei. (MJP; CR; processo cível; ação de liberdade de Maria, africana; caixa 1161; anos 1882-1885). 
que ainda guardam "marcas" do passado escravista, tal como a denominada Rua das Creoulas, no bairro das Graças, indicando que, no passado, elas viviam nas imediações, entre tensões e solidariedades ${ }^{10}$. Enfim, faziam a vida da melhor maneira possível.

\section{Referências Bibliográficas}

BARBOSA, Virgínia. Hospital Pedro II. Pesquisa Escolar Online, Fundação Joaquim Nabuco, Recife, 26 de novembro de 2008. (Atualizado em 14 de setembro de 2009). Disponível em: $<$ http://basilio.fundaj.gov.br/pesquisaescolar/>. Acesso em: 27 jul. 2016.

BRASIL. Código do Processo Criminal do Império. 2. ed. Rio de Janeiro: Empreza Nacional do Diário. 1857.

BRASIL. Império. Decreto 5135 de 13 de novembro de 1872. Ementa: Approva o regulamento geral para a execução da lei $\mathrm{n}^{\mathrm{o}} 2040$ de 28 de setembro de 1871. Disponível em: $<$ http://www2.camara.leg.br/legin/fed/decret/1824-1899/decreto-5135-13-novembro-1872551577-publicacaooriginal-68112-pe.html>. Acesso em: 25 set. 2016.

BRASIL. Império. Lei de 7 de novembro de 1831. Ementa: Declara livres todos os escravos vindos de fôra do Imperio, e impõe penas aos importadores dos mesmos escravos. Disponível em: $<$ http://www2.camara.leg.br/legin/fed/lei_sn/1824-1899/lei-37659-7-novembro-1831-564776publicacaooriginal-88704-pl.html>. Acesso em: 25 set. 2016.

BRASIL. Império. Lei $n^{\circ} 2.040$ de 28 de setembro de 1871. Ementa: Declara de condição livre os filhos de mulher escrava que nascerem desde a data desta lei, libertos os escravos da Nação e outros, e providencia sobre a criação e tratamento daquelles filhos menores e sobre a libertação annaul de escravos. Disponível em: $<$ http://www.planalto.gov.br/ccivil_03/leis/lim/LIM2040.htm>. Acesso em: 25 set. 2016.

CHIAVENATO, Júlio José. O negro no Brasil: da senzala à guerra do Paraguai. São Paulo: Brasiliense, 1987.

DEL PRIORE, Mary; PINTO, Renato. Ancestrais: uma introdução à História da África Atlântica.

10A denominação Ruas das Creoulas chamou-nos a atenção desde o primeiro momento que a identificamos, ao chegar no Recife. Deixou de ser curiosidade e passou a ser inquietação. Revistamos o Recife do XIX através das notícias do Diario de Pernambuco por uma década (1880 a 1889). Registramos 70 ocorrências das mais diversas: "No dia 7 do corrente, ausentou-se da casa da sua senhora a escrava Cosma, de 25 anos de idade, pouco mais ou menos, alta, cheia do corpo, tem uma bellinde no olho direito e uma cicatriz na nuca, proveniente de um caustico de coita roxa, o que é de supor que mais fará uso, costuma andar pelas ruas da Boa Vista: roga-se as autoridades policiaes e capitais de campo apprhensão da mesma e levar à Capunga, n. 47, Rua das Creoulas, que serão recompensados (DIARIO DE PERNAMBUCO, 12 de maio de 1870); "Recosa-se de uma ama para casa de pouca família, preferindo-se escrava: na Capunga, Rua das Creoulas, n. 35 (DIARIO DE PERNAMBUCO, 22 de julho de 1879); “Acidente; Ante-hontem, às 10 horas da noite, o trem de Caxangá, ao passar pela rua das Creoulas na freguesia das Graças, camagou o indivíduo de nome Plácido, de cor preta, livre, de 30 anos de idade (DIARIO DE PERNAMBUCO, 27 de abril de 1887); "Precisa-se de uma ama para cuidar de crianças, na rua das Creoulas (Capunga) (DIARIO DE PERNAMBUCO, 11 de janeiro de 1888). 
Rio de Janeiro: Campus, 2004.

DIARIO DE PERNAMBUCO. 1833. 27 mar.

DIARIO DE PERNAMBUCO. 1833. 26 jun.

DIARIO DE PERNAMBUCO. 1837. 16 nov.

DIARIO DE PERNAMBUCO. 1851. 12 jun.

DIARIO DE PERNAMBUCO. 1854. 28 jul.

DIARIO DE PERNAMBUCO. 1854. 22 set.

DIARIO DE PERNAMBUCO. 1855. 27 out.

DIARIO DE PERNAMBUCO. 1856. 28 jan.

DIARIO DE PERNAMBUCO. 1856. 15 mar.

DIARIO DE PERNAMBUCO. 1856. 14 maio.

DIARIO DE PERNAMBUCO. 1856. 15 set.

DIARIO DE PERNAMBUCO. 1856. 26 dez.

DIARIO DE PERNAMBUCO. 1861. 20 maio.

DIARIO DE PERNAMBUCO. 1861. 27 jun.

DIARIO DE PERNAMBUCO. 1862. 13 jan.

DIARIO DE PERNAMBUCO. 1870. 12 maio.

DIARIO DE PERNAMBUCO. 1879. 22 jul.

DIARIO DE PERNAMBUCO. 1881. 6 jul.

DIARIO DE PERNAMBUCO. 1881. 13 jul.

DIARIO DE PERNAMBUCO. 1887. 27 abr.

DIARIO DE PERNAMBUCO. 1888. 11 jan.

FERNANDES, Cyra Luciana Ribeiro de Oliveira. Os africanos livres em Pernambuco (1831-1861). Dissertação (Mestrado em História) - Programa de Pós-Graduação em História, Universidade Federal de Pernambuco. Recife, 2010.

FILME 12 Anos De Escravidão. Diretor: Steve McQueen. Lançado em 2014.

FOUCAULT, Michel. Microfisica do Poder. Rio de Janeiro: Graal, 1979. 
FUNDAÇÃO BIBLIOTECA NACIONAL. Biblioteca Nacional Digital. Disponível em: $<$ http://memoria.bn.br/hdb/uf.aspx>. Acesso em: 29 maio 2017.

GORENDER, Jacob. Violência, consenso e contratualidade. In: São Paulo: Ática, 1990.

KARASCH, Mary. A vida dos escravos no Rio de Janeiro (1808-1850). São Paulo: Cia. das Letras, 2000.

MATTOSO, Kátia M. de Queirós. Ser escravo no Brasil. SP: brasiliense, 1982.

MELLASSOUX, Claude. Antropologia da escravidão. Rio de Janeiro: Zahar, 1995.

MEMORIAL DA JUSTIÇA DO ESTADO DE PERNAMBUCO (MPJ). COMARCA DO RECIFE (CR). Processo Cível; caixa 1161; ano: 1884; Folhas: 02.

MEMORIAL DA JUSTIÇA DO ESTADO DE PERNAMBUCO (MPJ). COMARCA DO RECIFE (CR). Processo Cível; caixa 1176; ano 1883; folhas 15-15vv.

MEMORIAL DA JUSTIÇA DO ESTADO DE PERNAMBUCO (MPJ). COMARCA DO RECIFE (CR). Processo Cível; ação de liberdade de Maria, africana; caixa 1161; anos 1882-1885.

MEMORIAL DA JUSTIÇA DO ESTADO DE PERNAMBUCO (MPJ). COMARCA DO RECIFE (CR). Processo Cível; caixa 1161, ano 1882.

MEMORIAL DA JUSTIÇA DO ESTADO DE PERNAMBUCO (MPJ). COMARCA DO RECIFE (CR). Processo Cível; caixa 1161; ano 1884; folha 2.

MEMORIAL DA JUSTIÇA DO ESTADO DE PERNAMBUCO (MPJ). Processo Cível; caixa 1161; ano 1884; folhas 06-06v).

MEMORIAL DA JUSTIÇA DO ESTADO DE PERNAMBUCO (MPJ). Processo Cível; caixa 1176; ano 1883; folha 06.

MEMORIAL DA JUSTIÇA DO ESTADO DE PERNAMBUCO (MPJ). Processo Cível; caixa 1176; ano 1883; folha 07.

MEMORIAL DA JUSTIÇA DO ESTADO DE PERNAMBUCO (MPJ). Processo Cível; caixa 1176; ano 1883; folhas [ilegível].

MEMORIAL DA JUSTIÇA DO ESTADO DE PERNAMBUCO (MPJ). Processo Cível; caixa 1176; ano 1883; folhas 03v.

MEMORIAL DA JUSTIÇA DO ESTADO DE PERNAMBUCO (MPJ). Processo Cível; caixa 1176; ano 1883; folhas $03 \mathrm{v}-04$.

MEMORIAL DA JUSTIÇA DO ESTADO DE PERNAMBUCO (MPJ). Processo Cível; caixa. 1161; ano 1884; folhas 013v-014.

MEMORIAL DA JUSTIÇA DO ESTADO DE PERNAMBUCO (MPJ). Processo Cível; inventário de um africano; caixa 1223; ano 1867; folha 13. 
MOURA, Clovis. Dicionário da escravidão negra no Brasil. São Paulo: Edusp, 2004.

OLIVEIRA, Maria Inês Cortês de. O liberto: o seu mundo e os outros. Salvador: Corrupio, 1988.

REIS, João José; SILVA, Eduardo. Negociação e Conflito. São Paulo: Cia. das Letras, 1999.

SANTOS, Jocélio Teles dos. Pretos disfarçados a branco pouco claro: classificações raciais no Brasil dos séculos XVIII e XIX. Afro-Ásia, v. 32, 2005. p. 115-137.

SANTOS, Maria Emília Vasconcelos dos. O 25 de março de 1884 e a luta pela libertação dos escravos em Pernambuco. Clio, Revista de Pesquisa Histórica, n. 33.2. (2015). Disponível em: $<$ https://periodicos.ufpe.br/revistas/revistaclio/article/view/24503/0>. Acesso em: 20 out. 2016.

SILVA, José Bento Rosa da. Caetanos \& Caetanos: tradição oral e História (em preto \& branco). Itajaí: Editora do autor, 2008.

SLENES, R. Na Senzala uma Flor. Rio de Janeiro: Nova Fronteira, 1999.

TEIXEIRA, Luana. Comércio Interprovincial de escravos em Alagoas no Segundo Reinado. [Tese de Doutorado - Recife: CFCH, Programa de Pós-Graduação em História, 2016.

VAINFAS, Ronaldo. Ideologia e escravidão: os letrados e a sociedade escravista no Brasil. Petrópolis: Vozes, 1986.

WIKIPÉDIA. Numeração das artes. Disponível em: <https://pt.wikipedia.org/wiki/Numera \%C3\%A7\%C3\%A3o_das_artes>. Acesso em: 26 jul. 2016. 